\title{
Efficacy of Libidibia ferrea var. ferrea and Agave sisalana Extracts against Dactylopius opuntiae (Hemiptera: Coccoidea)
}

\author{
Rosineide S. Lopes ${ }^{1}$, Luciana G. Oliveira ${ }^{1}$, Antonio F. Costa ${ }^{1}$, Maria T. S. Correia ${ }^{2}$, Elza A. Luna-Alves Lima ${ }^{3}$ \\ \& Vera L. M. Lima ${ }^{2}$ \\ ${ }^{1}$ Agronomic Institute of Pernambuco (IPA), Recife, Brazil \\ ${ }^{2}$ Department of Biochemistry, Federal University of Pernambuco (UFPE), Recife, Brazil \\ ${ }^{3}$ Department of Mycology, Federal University of Pernambuco (UFPE), Recife, Brazil \\ Correspondence: Vera L. M. Lima, Departamento de Bioquímica, Universidade Federal de Pernambuco, Av. Prof. \\ Moraes Rego, s/n, Cidade Universitária, Recife, PE, CEP: 50670-420, Brazil. Tel: 55-(81)-2126-8576. E-mail: \\ lima.vera.ufpe@gmail.com
}

Received: December 18, 2017

Accepted: January 24, $2018 \quad$ Online Published: March 15, 2018

doi:10.5539/jas.v10n4p255

URL: https://doi.org/10.5539/jas.v10n4p255

The research is financed by "Fundação de Amparo à Ciência e Tecnologia do Estado de Pernambuco" (FACEPE), National Council for Scientific and Technological Development (CNPq), Coordination for the Improvement of Higher Level -or Education- Personnel) (CAPES), and "Banco do Nordeste do Brasil" (BNB).

\begin{abstract}
The carmine cochineal (Dactylopius opuntiae) is an insect-plague of Opuntia ficus-indica palm crops, causing losses in the production of the vegetable used as forage for the Brazilian semiarid animals. The objective of this work was to analyze the efficacy of plant extracts, insecticides and their combination in the control of $D$. opuntiae. Leaf and pod extracts of Libidibia ferrea var. ferrea, Agave sisalana leaf at concentrations 10, 25, 50, 100 and $200 \mathrm{mg} / \mathrm{mL}$, and insecticides (chlorpyrifos, acetamiprid, thiamethoxam and lamba-cyhalothrin) at concentrations minimum, median and maximum; were applied on cladodes infested by D. opuntiae. After 10 days of treatment, the percentages of mortality and $\mathrm{LC}_{50}$ (concentration to kill $50 \%$ of cochineal) were obtained on the stages of nymphs II and adult females. The association between the $\mathrm{LC}_{50}$ of the plant extracts with the insecticides on the cochineal it was tested. The results showed that $L$. ferrea extracts were more effective against cochineal, causing the $81 \%$ of nymphal II mortality $\left(\mathrm{LC}_{50}: 20\right.$ to $\left.160 \mathrm{mg} / \mathrm{mL}\right)$ and $97 \%$ of adult females $\left(\mathrm{LC}_{50}\right.$ : 43 to $50 \mathrm{mg} / \mathrm{mL}$ ), whereas the extracts of A. sisalana only controlled adult females, causing the mortality from 51 to $97 \%$ ( $\left(\mathrm{LC}_{50}: 17\right.$ to $\left.46 \mathrm{mg} / \mathrm{mL}\right)$. The insecticide chlorpyrifos was the most efficient on nymphs and adult females cochineal $\left(\mathrm{LC}_{50}: 0,084 \mathrm{~mL} / \mathrm{L}\right)$. The combination of this insecticide with the extracts promoted a percentage of mortality above $90 \%$. The extracts presented insecticidal potential on D. opuntiae and can be tested isolated or in combination with insecticides in control of cochineal.
\end{abstract}

Keywords: Agave sisalana, cochineal, insecticide, integrated pest control, Libidibia ferrea, plant extract

\section{Introduction}

The cactus Opuntia are used for various purposes such as food (fruit and fresh or dried cladodes) and forage for animals producing milk. They are also used as a substrate for the creation of the gender cochineal Dactylopius, producers of carminic acid (Medina, Rodríguez, \& Romero, 2007). Among these, Opuntia ficus-indica (L.) Mill. (Caryophyllales: Cactaceae), a cactaceous of Mexican origin it is an important for the economic development of arid and semiarid areas, particularly in Latin America, mainly in Brazil and Mexico, where the palm is widely used as a food source, especially for animals of dairy production, because of their content water $( \pm 90 \%)$ and nutrients as soluble carbohydrates, calcium and vitamins (Ennouri, Fetoui, Bourret, Zeghal, \& Attia, 2006; Vilela et al., 2010; Borges et al., 2013; Perez-Ramirez, Castrejón-Ayala, \& Jiménez-Pérez, 2014). The nutritional significance of the palm fruit give the ascorbic acid, content of fibers and free amin acids (Stintzing, Schieber, \& Carle, 2001), and the seed accumulates protein before fruit ripening (Walker, Famiani, Baldicchi, Cruz-Castillo, \& Inglese, 2011), with palm potential in medicine due to its anti-inflammatory action, antioxidant and prevention 
of ulcers (Galati, Mendello, Giuffrida, \& Miceli, 2001; Park, Kahng, Lee, \& Shin, 2001; Lee, H. R. Kim, J. Kim, \& Jam, 2002).

Diverse species of Opuntia cactus are parasitized by Dactylopius opuntiae Cockerell (Hemiptera: Coccoidea), including O. ficus-indica and O. cochenillifera (L.) (Chaves-Moreno, Tecante, \& Casas, 2009). In countries such as Peru, the Canary Islands, and Mexico, carmine cochineal is used to produce the natural coloring carmine that is used in the food industry; it can also be used in the biological control of some invader cactus species (Hoffmann, Moran, \& Zimmermann, 1999; Volchanski, Hoffmann, \& Zimmerman, 1999; Paterson et al., 2011). This insect attacks cultivated cacti in Brazil, Mexico, and other countries, causing severe losses of forage production and fruits, resulting in economic losses to farmers (Vigueras, Tovar, \& Pelayo-Ortiz, 2009; Silva, Mergulhão, Medeiros, Figueiredo, \& Burity, 2013; Bouharroud, Amarraque, \& Qessaoui, 2016; Tiago et al., 2016).

The use of chemical insecticides in pest control presents immediate results, however, can cause environmental imbalance, toxic residues in foods, diseases in humans and other animals and development of resistance mechanisms in insects (Pourseyed, Tavassoli, Bermousi, \& Mardani, 2010), and in the case of cochineal and the palm, there is not chemicals registered in Brazil. However, the use of chemical insecticides for the control of large outbreaks D. opuntiae infestation is recommended (Santos et al., 2006), and the use of resistant cultivars palms to keep the cochineal insect pest at levels which do not damage and increase the productivity of plantations (Borges et al., 2013; Falção, Oliveira, Mergulhão, Silva, \& Santos, 2013). In addition, an alternative to be tested for the control of D. opuntiae is the use of plant extracts.

Plant species are resistant to insect attack and this resistance can be mediated by the production and action of primary and secondary metabolites, such as proteins (lectins), alkaloids, tannins, and terpenoids (Souza et al., 2011). These substances have insecticidal action more beneficial compared to chemicals because they are renewable, easily degradable and do not contaminate the environment (Oliveira, Lins-Neto, Araújo, \& Albuquerque, 2007). Previous studies have reported the action the of extracts and vegetable oils and other bioactive substances in control of nymphs and adults of D. opuntiae (Vigueras et al., 2009; Vázquez-Garcia, Garabito-Espinoza, Tabares-Vega, \& Castillo-Herrera, 2011; Borges et al., 2013; Pérez-Ramirez et al., 2014; Santos, Oliveira, Costa, Tiago, \& Oliveira, 2015).

Libidibia ferrea var. ferrea (Mart. Ex Tul.) L.P. Queiroz (= Caesalpinia ferrea) (Fabales: Fabeaceae) is a legume tree distributed in the semiarid region of the North and Northeast of Brazil, known as ironwood or "jucá", being used in the pharmaceuticals industry, in construction and in folk medicine (Lorenzi, 2002; Queiroz, 2010). The chemical components present in the leaves, fruits and roots of $L$. ferrea exhibit anti-inflammatory, analgesic, antibacterial and healing properties and may be insecticidal action (Trentin et al., 2011; Freitas et al., 2012; Araújo et al., 2014; Carvalho, Sampaio, Araújo, Pinto, \& Rocha, 2016). In turn, the sisal, Agave sisalana Perrine ex Engelm (Asparagales: Agavaceae) is an herbaceous plant, native to Central America and Mexico and it is found in many tropical countries, such as Tanzania and Brazil (Chand, Tiwary, \& Rohatgi, 1988). Liquid waste and secondary sisal metabolites (alkaloids, saponins and tannins) have insecticidal action, and this action proved by the use of raw juice and extracts of A. sisalana in larvae of mosquitoes Aedes aegypti (L.) and in the control of spider mite Tetranyclus urticae (Koch.) (Barreto, Araújo, \& Bonifácio, 2010; Nunes et al., 2015).

The need to minimize economic losses caused by the cochineal, especially in Northeastern Brazil, has encouraged researchers to seek new alternatives to control this insect. Therefore, this study aimed to investigate the potential of L. ferrea and A. sisalana extracts and, chlorpyrifos, acetamiprid, thiamethoxam, and lambda-cyhalothrin insecticides as well as the combination of extracts and insecticides in controlling $D$. opuntiae.

\section{Material and Methods}

\subsection{Insect Collection and Rearing}

The cochineal D. opuntiae was collected in plantations of $O$. ficus-indica in the municipalities of "Sertão do Moxotó and Pajeú", Pernambuco State, Brazil. The insects were raised in culture chambers at $28 \pm 1{ }^{\circ} \mathrm{C}$, with $37 \pm 3 \%$ relative humidity $(\mathrm{RH})$, and $12 \mathrm{~h}$ photoperiod, on healthy cactus cladodes placed horizontally on wooden supports and infested with first stage nymphs. The biological trials used second stage nymphs and adult females of $D$. opuntiae after 12 and 40 days of infestation respectively, according to the durations of the biological cycle of D. opuntiae (Flores-Hernández et al., 2006). The cladodes with adult females were sprayed with a $2 \%$ solution of detergent before assay to improve contact of the suspensions with the insect bodies. 


\subsection{Preparation of Plant Extracts}

The leaves and pods L. ferrea and leaves of A. sisalana specimens were collected in Recife (Pernambuco/Brazil). The species were indentified in Botanic Department at Agronomic Institute of Pernambuco $\left(8^{\circ} 03^{\prime} 50.2^{\prime \prime} \mathrm{S}\right.$, $34^{\circ} 55^{\prime} 29.2^{\prime \prime} \mathrm{W}$ ), and after that the botanical material was deposited in Dárdano Andrade Lima Herbarium. After collection, the material was washed in distilled water to remove impurities, dried at room temperature and triturated. To obtain the aqueous extract of the leaves and pods of $L$. ferrea (AELLf and AEPLf), $20 \mathrm{~g}$ of plant material were mixed with $80 \mathrm{~mL}$ of $0.15 \mathrm{M} \mathrm{NaCl}$ solution to a final concentration of $200 \mathrm{mg} / \mathrm{mL}(\mathrm{w} / \mathrm{v})$. The suspension was stirred 16 hours at $4{ }^{\circ} \mathrm{C}$, then filtered and the extract was subjected to centrifugation at 10.000 rpm for 15 minutes at $4{ }^{\circ} \mathrm{C}$. For the methanol extract of L. ferrea (MELLf and MEPLf), $20 \mathrm{~g}$ of plant material were subjected to infusion methanolic (Sigma-Aldrich $\left.{ }^{\mathbb{B}}\right)(80 \mathrm{~mL})$ with stirring for 24 hours, the suspension filtered and the extract subjected to a rotary evaporator. For $A$. sisalana were made the aqueous extracts (AELAs) and hydroethanolic extract (HELAs), the aqueous extract obtained according to the protocol used for $L$. ferrea extract. For hydroethanolic extract, $20 \mathrm{~g}$ of vegetable underwent ethanolic infusion (Sigma-Aldrich ${ }^{\circledR}$ ) at $70 \%(80$ $\mathrm{mL}$ ) for two hours, and then filtered. Then, the alcohol was evaporated for 16 hours at $45^{\circ} \mathrm{C}$. The extracts at 200 $\mathrm{mg} / \mathrm{mL}$ were diluted with Tween $80(0.1 \%)$ solution to obtain concentrations of $100,50,25$ and $10 \mathrm{mg} / \mathrm{mL}$.

\subsection{Chemical Insecticides Used in the Experiments}

The chemical insecticides chlorpyrifos, acetamiprid, thiamethoxam, and lamba-cyhalothrin have been widely used for controlling Hemiptera insects such as cochineal, and are readily available commercially. These insecticides were tested at three different concentrations based on the recommendations of the manufacturers, with the median concentration (CMed) corresponding to that recommended for field use; the minimum concentrations (CMed/2) and maximum concentrations (CMedx2) are listed in Table 1.

\subsection{Effect of Chemical Insecticides and Plant Extracts on Dactylopius opuntiae}

For the D. opuntiae bioassays, cladodes infested with nymphs and adult females were sprayed with $10 \mathrm{~mL}$ of the extract concentrations, insecticides and with Tween $80(0.1 \%)$ solution (control) using a De Vilbiss $\mathrm{n}^{\mathrm{o}} 15$ manual sprayer. After spraying, the cladodes were placed in container $(30 \mathrm{~cm} \times 15 \mathrm{~cm} \times 08 \mathrm{~cm})$ and maintained at room temperature $\left(28 \pm 1^{\circ} \mathrm{C}\right)$, with $37 \pm 3 \% \mathrm{RH}$, for 10 days, then 50 adult females and 50 nymphs were collected from $64 \mathrm{~cm}^{2}$ of each palm $(8 \mathrm{~cm} \times 8 \mathrm{~cm})$. The experiments were performed in triplicate, totaling 150 females and 150 nymphs per treatment. The mortality counts were made using a stereo microscope, considering as dead those insects demonstrating color modifications, dehydrated or flaccid bodies, or without any movement. Then they determined the percentage of mortality and the Lethal Concentration $\left(\mathrm{LC}_{50}\right)$.

\subsection{Association Action between Plant Extracts and Pesticides on Dactylopius opuntiae}

For this bioassay, the suspensions were made with the combination of $\mathrm{LC}_{50}$ of each extract to $\mathrm{LC}_{50}$ of insecticides (Table 3). Then palms infested with nymphs and adult females were sprayed with $10 \mathrm{~mL}$ of suspensions associated and for the treatment control, palms were sprayed with only the extracts, insecticides and Tween $80(0.1 \%)$ solution (control). The palms were transferred to plastic containers and maintained at room temperature $\left(28 \pm 1^{\circ} \mathrm{C}\right)$, with $37 \pm 3 \% \mathrm{RH}$, for 10 days, then 50 adult females and 50 nymphs were collected from $64 \mathrm{~cm}^{2}$ of each palm $(8 \mathrm{~cm} \times 8 \mathrm{~cm})$, made three evaluations for treatment and mortality percentage nymphs and adult females was determined.

\subsection{Statistical Analyses}

Statistical analyses of the data were performed using the analysis of variance (ANOVA) and compared using the Tukey's test at a 5\% probability level of significance, using the Proc ANOVA software from SAS (SAS Institute, 1999-2001). The mean lethal concentration $\left(\mathrm{LC}_{50}\right)$ was determined by Proc Probit software (SAS Institute 1999-2001). The graphs were performed by the Prisma 6.0 software (Software GraphPad).

\section{Results}

All insecticides caused nymphal mortality and differ from the control treatment showed that mortality from $8 \%$ $(\mathrm{p}=0.05)$. The insecticide chlorpyrifos was the most efficient, causing $93 \%$ nymphal mortality with the lowest concentration $(0.75 \mathrm{~mL} / \mathrm{L})$, not differing from the other concentrations $(1.5$ and $3.0 \mathrm{~mL} / \mathrm{L})$. The other insecticides caused mortality from $53 \%$ to $80 \%$, and these means differ between the tested and the control treatment concentrations, the effect being directly proportional to pesticide concentration increases $(p=0.05)$. The insecticides chlorpyrifos ( $82 \%$ to $97 \%$ ) and lambda-cyhalothrin (62\% to $99 \%)$ were the most effective against cochineal adult females, with means of mortality differing between concentrations and with control $(p=0.05)$, and the control treatment showed an average mortality of $15 \%$ (Table 2). The insecticides acetamiprid and 
thiamethoxam caused mortality between $60 \%$ and $78 \%$ of adult females, with no statistical difference between the tested concentrations, but between these and the control there was statistical difference $(p=0.05)$.

The extracts $L$. ferrea had a positive effect on nymphs and adult females of $D$. opuntiae (Figure 1), being more efficient with increasing concentration $(\mathrm{p}=0.05)$. The MEPLf and MELLf showed higher insecticidal potential the nymphs on with average mortality of $82 \%$ and $80 \%$ respectively at the concentration of $200 \mathrm{mg} / \mathrm{mL}$, differing $(\mathrm{p}=0.05)$ from the control treatment $(12 \%)$ (Figures $1 \mathrm{c}$ and $1 \mathrm{~d})$. The extracts from the leaves $L$. ferrea (AELLf and MELLf) exhibited greater insecticidal effect on adult females of D. opuntiae, because with the higher concentration $(200 \mathrm{mg} / \mathrm{mL})$ caused mortality of $97 \%$ and $81 \%$ respectively, and all treatments differed statistically $(\mathrm{p}=0.05)$ from the control $(16 \%$ and $19 \%)$ (Figures $1 \mathrm{~b}$ and $1 \mathrm{~d})$.

Table 1. Chemical pesticides utilized for controlling cochineal (order Hemiptera).

\begin{tabular}{llllllc}
\hline \multirow{2}{*}{ Product's name } & Type of formulation & Chemical Type & Constituent Active & \multicolumn{3}{c}{$\begin{array}{c}\text { Concentration recommended by the } \\
\text { manufacturer (L) }\end{array}$} \\
\cline { 5 - 7 } & & & & Minimum & Median & Maximum \\
\hline Lorsban 480 BR & Emulsifiable concentrate & Organophosphate & Chlorpyrifos & $0.75 \mathrm{~mL} / \mathrm{L}$ & $1.5 \mathrm{~mL} / \mathrm{L}$ & $3.0 \mathrm{~mL} / \mathrm{L}$ \\
Mospilan & Soluble powder & Neonicotinoid & Acetamiprid & $0.125 \mathrm{~g} / \mathrm{L}$ & $0.25 \mathrm{~g} / \mathrm{L}$ & $0.5 \mathrm{~g} / \mathrm{L}$ \\
Actara 250 WG & Dispersible granules & Neonicotinoid & Thiamethoxam & $0.10 \mathrm{~g} / \mathrm{L}$ & $0.20 \mathrm{~g} / \mathrm{L}$ & $0.40 \mathrm{~g} / \mathrm{L}$ \\
Karatê ZEON 250CS & Encapsulated suspension & Pyrethroid & lambda-cyhalothrin & $0.50 \mathrm{~mL} / \mathrm{L}$ & $1.0 \mathrm{~mL} / \mathrm{L}$ & $2.0 \mathrm{~mL} / \mathrm{L}$ \\
\hline
\end{tabular}

Table 2. Percentage mortality nymphs and adult females of Dactylopius opuntiae treated with insecticides, in different concentrations.

\begin{tabular}{|c|c|c|c|c|c|c|c|c|}
\hline \multirow{4}{*}{ Insecticide } & \multicolumn{8}{|c|}{ Mortality $(\%)^{1}$} \\
\hline & \multicolumn{4}{|c|}{ Nymphs } & \multicolumn{4}{|c|}{ Adult females } \\
\hline & \multicolumn{4}{|c|}{ Concentration } & \multicolumn{4}{|c|}{ Concentration } \\
\hline & Control & Minimum & Median & Maximum & Control & Minimum & Median & Maximum \\
\hline Chlorpyrifos & $8 \mathrm{~b}$ & $93 a$ & $97 \mathrm{a}$ & $100 \mathrm{a}$ & $15 \mathrm{c}$ & $82 \mathrm{ab}$ & $92 \mathrm{~b}$ & $97 \mathrm{a}$ \\
\hline Acetamiprid & $8 \mathrm{~b}$ & $60 \mathrm{a}$ & $70 \mathrm{a}$ & $75 \mathrm{a}$ & $15 \mathrm{~b}$ & $60 \mathrm{a}$ & $68 \mathrm{a}$ & $70 \mathrm{a}$ \\
\hline Thiamethoxam & $8 \mathrm{c}$ & $64 \mathrm{a}$ & $80 \mathrm{ab}$ & $74 \mathrm{~b}$ & $15 b$ & $75 \mathrm{a}$ & $77 \mathrm{a}$ & $78 \mathrm{a}$ \\
\hline lambda-cyhalothrin & $8 \mathrm{c}$ & $53 \mathrm{a}$ & $67 \mathrm{ab}$ & $77 \mathrm{~b}$ & $15 \mathrm{~d}$ & $62 \mathrm{c}$ & $80 \mathrm{~b}$ & $99 \mathrm{a}$ \\
\hline $\mathrm{CV}(\%)^{2}$ & 15.45 & & & & 5.58 & & & \\
\hline
\end{tabular}

Note. ${ }^{1}$ Means followed by the same letters do not significantly differ at a $5 \%$ probability level by the Tukey test.

${ }^{2} \mathrm{CV}$ : coefficient of variation. 


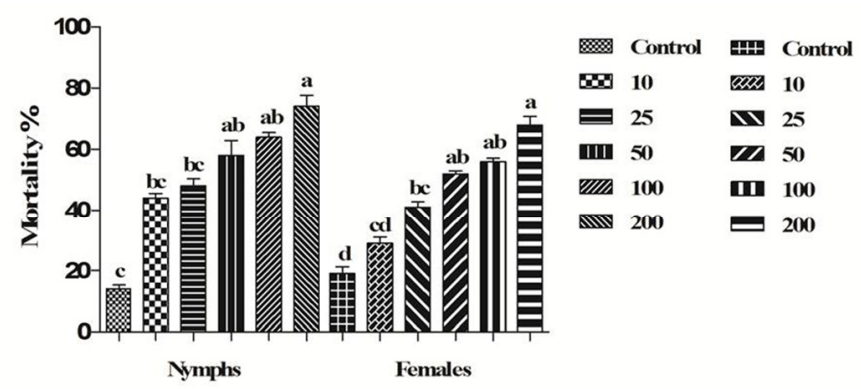

b
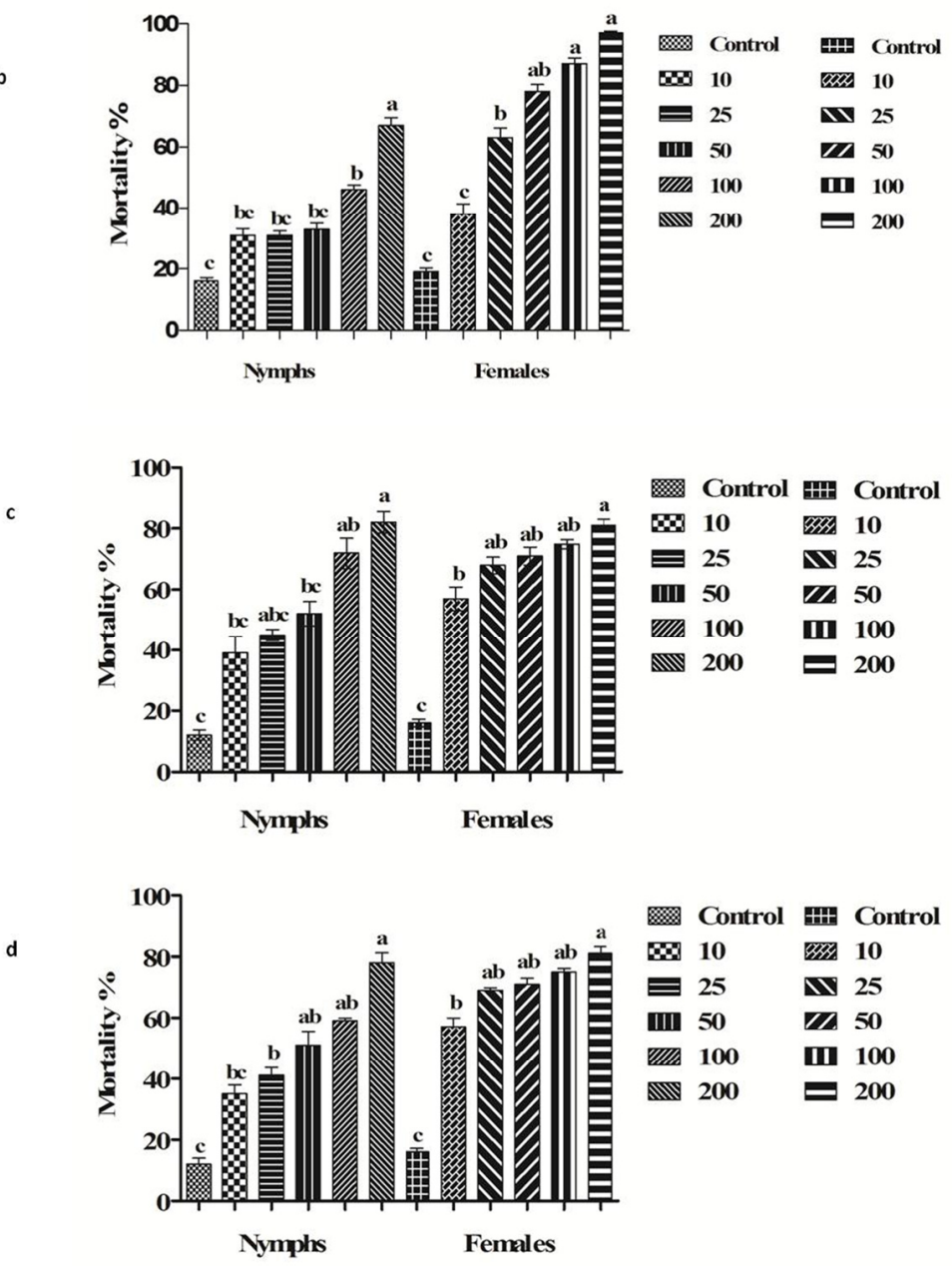

Figure 1. Mortality of nymphs and adult females of Dactylopius opuntiae treated by Libidibia ferrea extracts $(\mathrm{mg} / \mathrm{mL})$. AEPLf (a); AELLf (b) MEPLf (c); MELLf (d)

Note. Different letters in bars differ statistically at a $5 \%$ probability level by the Tukey test.

The AELAs and HELAs were not efficient in the control of nymphs from the carmine cochineal, showing average mortality ranging from $24 \%$ to $48 \%$ at the concentrations tested $(p=0.05)$ (Figures $2 a$ and $2 b)$. On the other hand, the HELAs was more efficient in the control of adult females, causing mortality of $51 \%$ to $95 \%$. The HELAs got greater potential insecticide on adult females with increasing concentrations and was statistical difference $(p=0.05)$ between the mean concentrations and the control treatment $(10 \%)$ (Figure $2 b)$. 

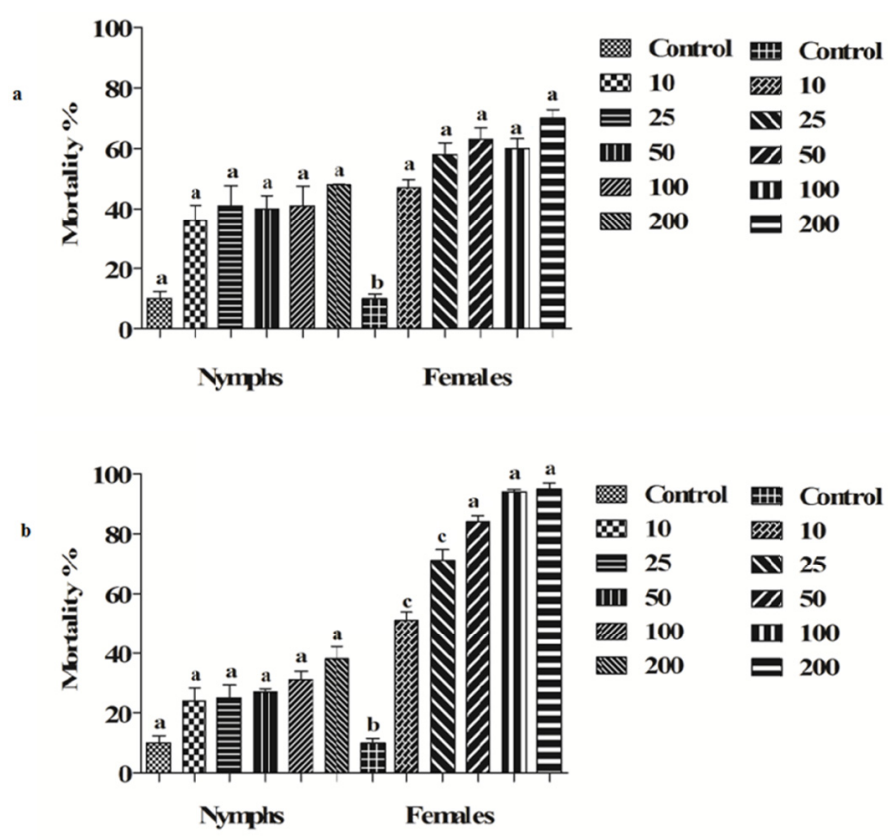

Figure 2. Mortality of nymphs and adult females of Dactylopius opuntiae treated Agave sisalana extracts $(\mathrm{mg} / \mathrm{mL})$. AELAs (a); HELAs (b)

Note. Different letters in bars differ statistically at a $5 \%$ probability level by the Tukey test.

It was observed that the insecticides and plant extracts caused degradation of the protective wax of the body of nymphs and adult females of $D$. opuntiae and subsequent dehydration and their mortality (Figure 3).

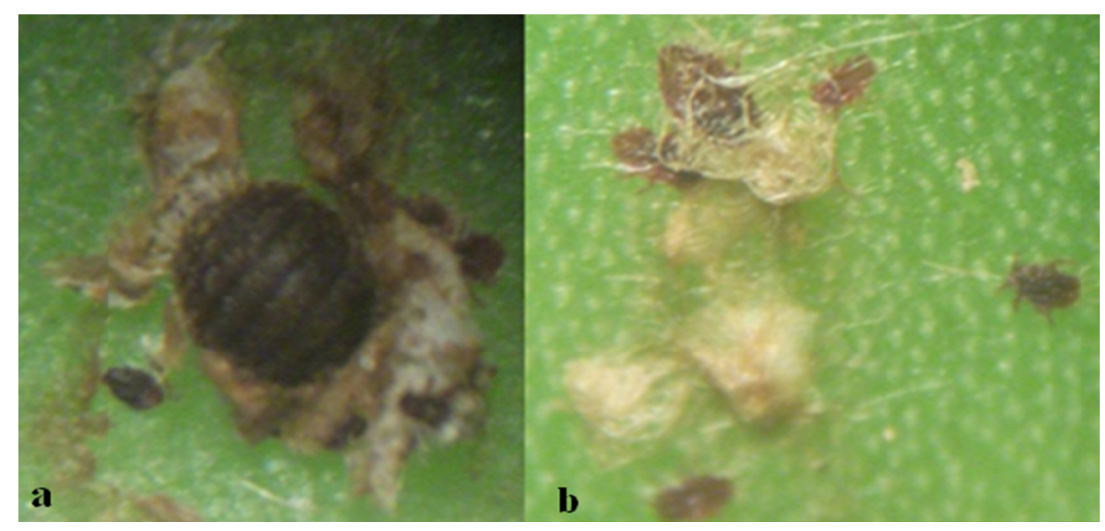

Figure 3. Effect methanolic leaves extract of Libidibia ferrea on adult female (a) and nymphs (b) of Dactylopius opuntiae

The values of lethal concentrations of plant extracts and pesticides on the nymphs and adult females of $D$. opuntiae are shown in Table 3 . The $\mathrm{LC}_{50}$ values presented by the insecticide were much lower than the concentrations (minimum, median and maximum) of these tested on nymphs and adult females. The MEPLf and MELLf showed lower $\mathrm{LC}_{50}$ values for nymphs $\left(20 \mathrm{mg} / \mathrm{mL}\right.$ and $32 \mathrm{mg} / \mathrm{mL}$, respectively), while the lowest $\mathrm{LC}_{50}$ values for adult females were $43 \mathrm{mg} / \mathrm{mL}$ (AELLf) and $17 \mathrm{mg} / \mathrm{mL}$ (HELAs). 
Table 3. Lethal concentration $\left(\mathrm{LC}_{50}\right)$ of chemical insecticides and plant extracts on Dactylopius opuntiae.

\begin{tabular}{|c|c|c|c|c|c|c|}
\hline & \multicolumn{3}{|c|}{ Nymphs } & \multicolumn{3}{|c|}{ Adult females } \\
\hline & $\mathrm{LC}_{50}(\mathrm{CI})^{1}$ & Regression Equation & $\left(\chi^{2}\right)^{2}$ & $\mathrm{LC}_{50}(\mathrm{CI})$ & Regression Equation & $\left(\chi^{2}\right)$ \\
\hline Chlorpyrifos & $0.084 \mathrm{~mL} / \mathrm{L}(0.011-0.062)$ & $\mathrm{Y}=6.69896+1.58005 * \log \mathrm{X}$ & 13.30 & $0.084 \mathrm{~mL} / \mathrm{L}(0.115-0.0598)$ & $\mathrm{Y}=6.14107+1.06547 * \log \mathrm{X}$ & 34.83 \\
\hline Acetamiprid & $0.883 \mathrm{~g} / \mathrm{L}(0.108-0.070)$ & $\mathrm{Y}=6.37602+1.30568 * \log \mathrm{X}$ & 40.66 & $0.054 \mathrm{~g} / \mathrm{L}(0.067-0.038)$ & $Y=6.32907+1.03806 * \log X$ & 40.66 \\
\hline Thiamethoxam & $0.089 \mathrm{~g} / \mathrm{L}(0.108-0.724)$ & $\mathrm{Y}=6.39356+1.32660^{*} \log \mathrm{X}$ & 28.82 & $0.072 \mathrm{~g} / \mathrm{L}(0.094-0.54)$ & $\mathrm{Y}=6.04968+0.92081 * \log \mathrm{X}$ & 14.67 \\
\hline Lambda-Cyhalothrin & $0.348 \mathrm{~mL} / \mathrm{L}(0.464-0.256)$ & $\mathrm{Y}=5.40824+0.89150 * \log \mathrm{X}$ & 40.51 & $0.127 \mathrm{~mL} / \mathrm{L}(0.169-0.092)$ & $Y=5.93508+1.04520 * \log X$ & 29.30 \\
\hline \multirow{2}{*}{ Plants extracts } & \multicolumn{3}{|c|}{ Nymphs } & \multicolumn{3}{|c|}{ Adults females } \\
\hline & $\mathrm{LC}_{50} \mathrm{mg} / \mathrm{mL}(\mathrm{CI})$ & Regression Equation & $\left(\chi^{2}\right)$ & $\mathrm{LC}_{50} \mathrm{mg} / \mathrm{mL}(\mathrm{CI})$ & Regression Equation & $\left(\chi^{2}\right)$ \\
\hline AEPLf & $150(240-9.15)$ & $\mathrm{Y}=4.92593+0.41688 * \log \mathrm{X}$ & 38.36 & $46(8.15-2.80)$ & $\mathrm{Y}=4.73885+0.39348 * \log \mathrm{X}$ & 29.05 \\
\hline AELLf & $160(38.36-8.54)$ & $\mathrm{Y}=4.56417+0,36212 * \log \mathrm{X}$ & 40.17 & $43(0.61-0,28)$ & $Y=5.24981+0.68520 * \log X$ & 77.36 \\
\hline MEPLf & $20(2.82-1.48)$ & $\mathrm{Y}=4.79742+0.64363 * \log \mathrm{X}$ & 67.97 & $50(0.75-0.33)$ & $\mathrm{Y}=5.16841+0.58266 * \log \mathrm{X}$ & 25.34 \\
\hline MELLf & $32(4.74-2.24)$ & $\mathrm{Y}=5.40824+0.89150 * \log \mathrm{X}$ & 45.64 & $47(0.71-0.29)$ & $\mathrm{Y}=5.17571+0.25889 * \log \mathrm{X}$ & 21.65 \\
\hline AELAs & - & - & - & $17(2.51-1.17)$ & $\mathrm{Y}=4.87128+0.37508 * \log \mathrm{X}$ & 36.42 \\
\hline HELAs & - & - & - & $46(0.62-0.33)$ & $Y=5.29697+0.90229 * \log X$ & 47.96 \\
\hline
\end{tabular}

Note. ${ }^{1} 95 \%$ Confidence interval. ${ }^{2}$ Chi-square test, as calculated by Probit.

The Figures 4, 5 and 6 show the potential involvement of the $\mathrm{LC}_{50}$ extracts of L. ferrea and A. sisalana with the $\mathrm{LC}_{50}$ of chlorpyrifos insecticides, acetamiprid, thiamethoxam and lambda-cyhalothrin on D. opuntiae. The associations of the extracts with insecticides were efficient on the nymphs and adult females, occurring a synergism in the association, in general, with the increase in the percentage of insect mortality compared with the products tested alone, with the highest mortality $D$. opuntiae was caused by the combination of extracts with insecticide chlorpyrifos (above 90\%), which differed from other treatments and control $(p=0.05)$.

a

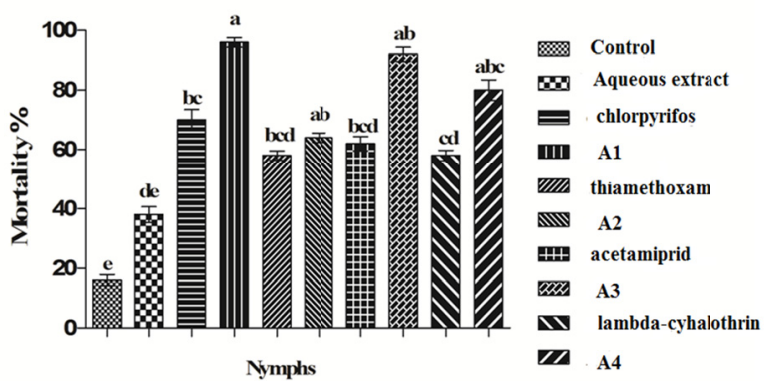

c

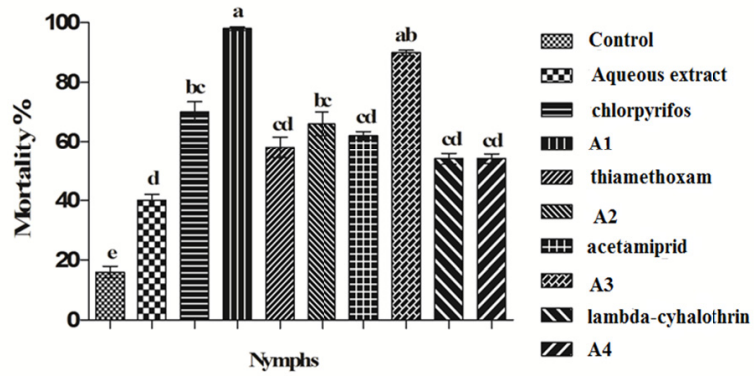

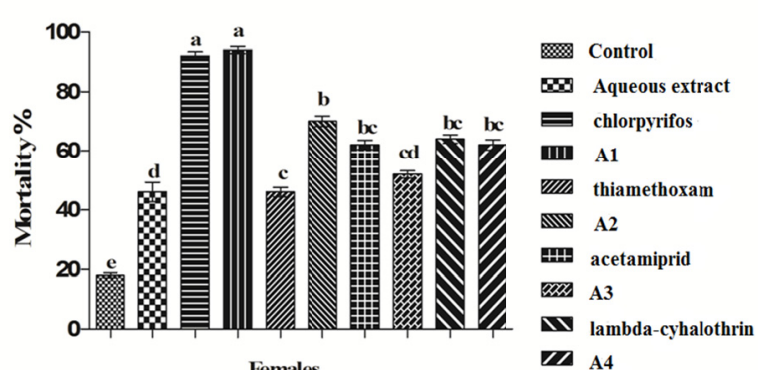

d

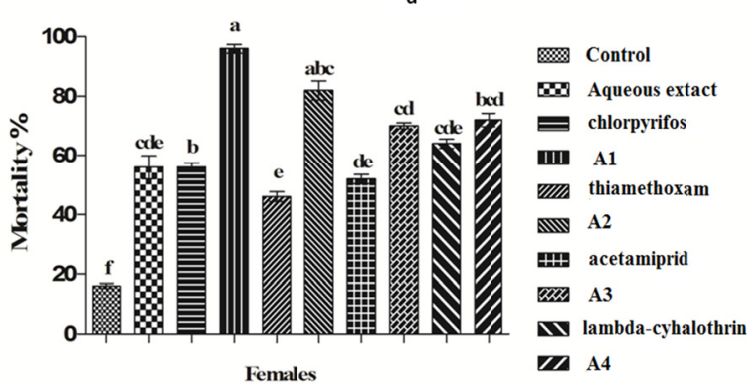

Figure 4. Effect of insecticides and aqueous extracts of Libidibia ferrea association on nymphs and adult females of Dactylopius opuntiae: AELLf ( $\mathrm{a}$ and b) and AEPLf (c and d). Treatments: Control, $\mathrm{LC}_{50}$ of extracts, $\mathrm{LC}_{50}$ and

$\mathrm{LC}_{50}$ of insecticides associations (A1: extract + chlorpyrifos, A2: thiamethoxam+extract, A3: extract + acetamiprid, A4: extract + lambda-cyhalothrin)

Note. Different letters in bars differ statistically at a $5 \%$ probability level by the Tukey test. 

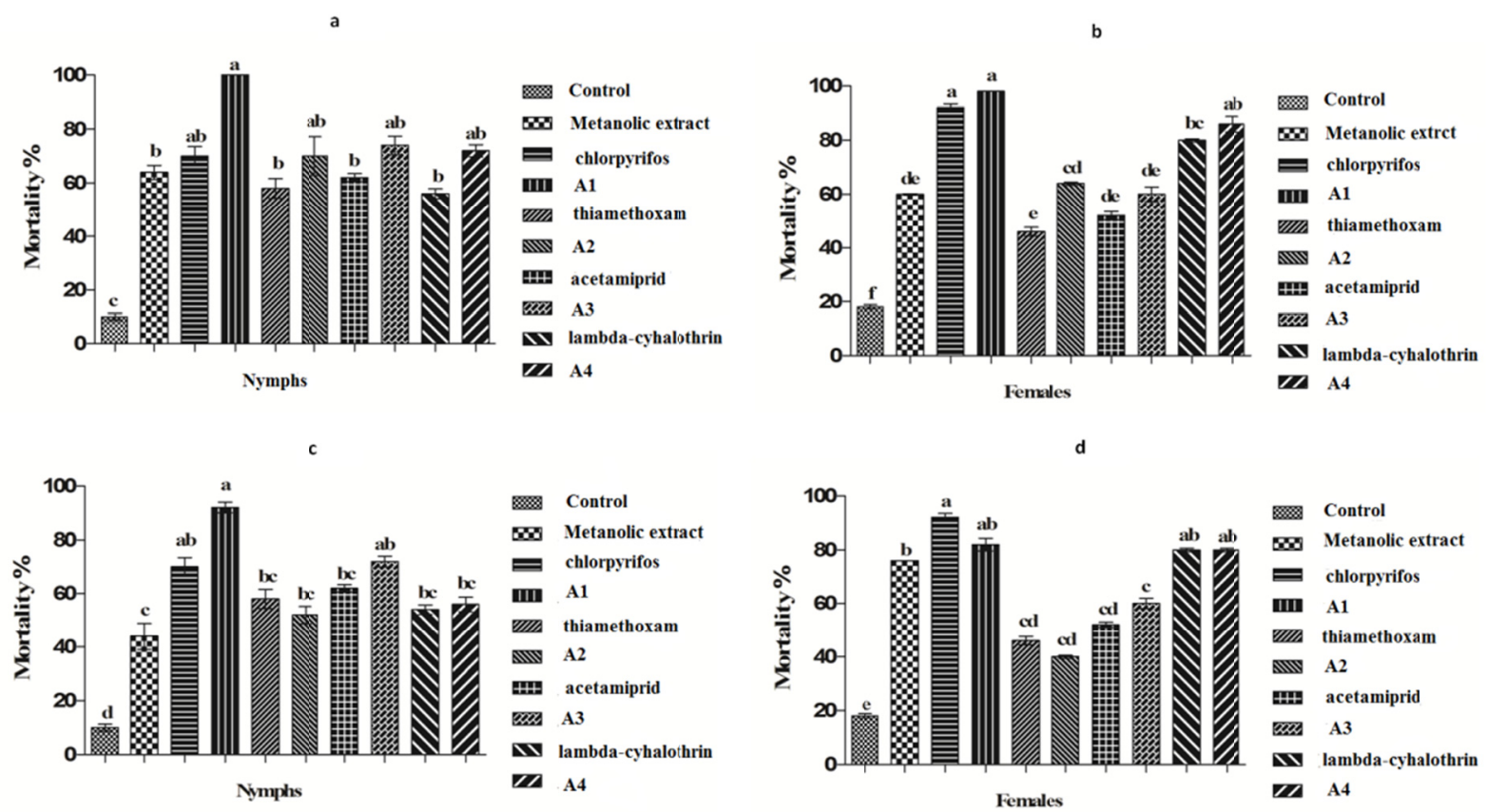

Figure 5. Effect of insecticides and methanol extracts of Libidibia ferrea association on nymphs and adult females of Dactylopius opuntiae: MELLf ( $\mathrm{a}$ and b) and MEPLf (c and d). Treatments: Control, $\mathrm{LC}_{50}$ of extracts and insecticides, $\mathrm{LC}_{50}$ and $\mathrm{LC}_{50}$ of insecticides associations (A1: extract + chlorpyrifos, $\mathrm{A} 2$ : thiamethoxam + extract, A3: extract + acetamiprid, A4: extract + lambda-cyhalothrin)

Note. Different letters in bars differ statistically at a 5\% probability level by the Tukey test.

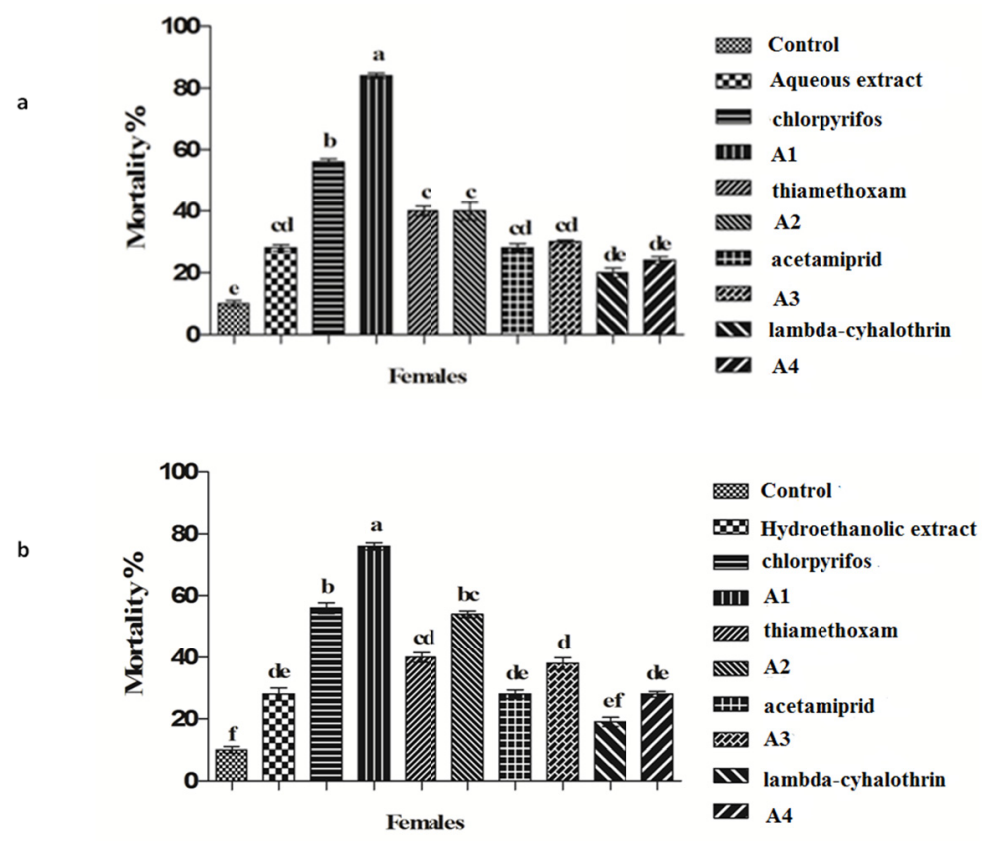

Figure 6. Effect of combination of insecticides with the aqueous extract (a) and hydroethanolic (b) of Agave sisalana on adult females of Dactylopius opuntiae. Treatments: Control, $\mathrm{LC}_{50}$ of extracts, $\mathrm{LC}_{50}$ and $\mathrm{LC}_{50}$ of insecticides associations (A1: extract + chlorpyrifos, A2: thiamethoxam+extract, A3: extract + acetamiprid, A4: extract + lambda-cyhalothrin)

Note. Different letters in bars differ statistically at a $5 \%$ probability level by the Tukey test. 


\section{Discussion}

Pesticides and plant extracts caused the nymphs and adult females of D. opuntiae mortalities, at the concentrations tested. Palacios-Mendonza, Nieto-Hernández, LlanderaL-Cázares, and Gonzáles-Hernándes (2004) and Vigueras et al. (2009) have reported the importance of degradation of the wax covering the body of the nymphs and adults female cochineal carmine of biodegradable products such as detergents and plant extracts, which cause dehydration and subsequent death of $D$. opuntiae. It was observed the degradation of the wax that covers the body of nymphs and adult females of $D$. opuntiae, after application of insecticides and especially of $L$. ferrea and A. sisalana extracts, and therefore, dehydration and death of the insects. These data are similar to those reported by Nobel (2001) and Flores-Hernández et al. (2006) which reported the products tested on the control of $D$. opuntiae present substances that degrade the wax layer, which is able to repel aqueous solutions and protect the insect. Santos et al. (2006) recommended for the control of large focus of $D$. opuntiae infestation, first cutting and incineration of cladodes contaminated, and the use of chemical products such as imidacloprid, triacloprid, thiamethoxam, chlorpyrifos, acetamiprid, carbaryl and lambda-cyhalothrin. Thus, it becomes necessary to establish a minimum concentration of these insecticides to minimize the impending risks of these products to the environment, or to use them in combination with other forms of control.

The thiamethoxam, chlorpyrifos, acetamiprid and lambda-cyhalothrin insecticides were effective on nymphs and adult females. The chlorpyrifos showed more potential of control carmine cochineal, promoting the death of more than $90 \%$ of the insects with the lower concentration $\left(\mathrm{LC}_{50} 0.084 \mathrm{mg} / \mathrm{mL}\right)$ for nymphs and adult females. The insecticide efficiency is determined by the minimum chemical concentration necessary to cause insect death and this variable concentration according to existing products, various physiological reactions of insects, among other causes. There are few studies on the effects of pesticides and the minimum concentration to control $D$. opuntiae, and the data found in this research are important for the development of efficient techniques to control this insect. Vigueiras et al. (2009) reported that the insecticide Agrobion ${ }^{\circledR} 400$ at 3\% promoted the death of 85\% and $100 \%$ of nymphs and adult females of D. opuntiae, respectively.

With the exception of the AELAs, and extracts HELAs to the nymphs, all other extracts showed insecticidal activity against nymphs and adult females of $D$. opuntiae, suggesting that these are formed by primary or secondary metabolites that have biopesticide potential against insect since caused the death of nymphs and adult females at the concentrations tested. The vegetables produce bioactive substances that are harmless to man and the environment and are considered alternative sources in the discovery of natural insecticides (Luna et al., 2005; Omena et al., 2007). These substances, such as lectins, alkaloids, tannins, terpenoids, glycosides, phenolic, phenylpropanoids must have attractive properties, deterrents and insecticide (Cheng, Chang, Wu, \& Chang, 2007; Melo-Santos, Araújo, Rios, \& Regis, 2009; Souza et al., 2011). The MEPLf and MELLf extracts were the most efficient in the control of nymphs, and this action possibly mediated by secondary metabolites of lipid origin, not found in the aqueous extracts tested, because these substances are extracted only by organic solvents such as methanol.

The insecticidal activity of $L$. ferrea extracts can be explained by the toxicity presented by their primary and secondary compounds. Previous chemicals studies leaf extract, stem and bark L. ferrea reported the presence of flavonoids, saponines, tannins, gallic acid, coumarins, steroids and phenolic compounds (Gonzales, Barros, \& Bach, 2004; Wyrepkowski et al., 2014). According Vázquez-García et al. (2011) the toxicity of oils essential and plant extracts of Ocimum basilicum L., Mentha spicata L., Cymbopogon winterianus (Jowitt) and Lippia graveolens Kunth on first instars D. opuntiae, $M$. spicata were the most efficient. Due to its characteristics of toxicity and repellency of insects, commercial terpenoids Egenol 99\% (Across Organics, Mexico), 1.8-Cineol 99\% and 99\% Menthol (Sigma Aldrich, Mexico) were analyzed on D. opuntiae, and products significantly reduced the insect fixation on the palm of cladodes (Pérez-Ramirez et al., 2014).

The extracts L. ferrea leaves (AELLf and MELLf) and HELAs were more bioactive against adult females, at the concentrations tested. Vigueiras et al. (2009) found similar results when they tested the Chenopodium ambrosioides L., Mentha piperita L., M. viridis L., Tagetes erecta L. and T. florida Sweet extract on D. opuntiae, with the mortality rate of between $35 \%$ nymphs and $98 \%$ for adult females, suggesting that the terpenoids present in extracts may be responsible for toxicity. Similarly, Santos et al. (2015) observed the effect of aqueous and hydroethanolic extracts Ricinus communis L. and Poincianella pyramidalis (Tul.) LP Queiroz (5, 10 and $20 \%$ ) on the females of $D$. opuntiae, and observed for mortality $61.23 \%$ to $100 \%$. The neem oil action was tested on colonies of $D$. opuntiae, in concentrations of $1 \%, 2 \%$ and $3 \%$ causing significant reduction of the insects, with the elimination of most colonies of D. opuntiae on cladode (Gorlach-Lira \& Lira, 2011). Also, Borges et al. (2013) verified the effect of neutral detergent, cassava starch, of liquid waste generated from the processing of cassava, mineral oil and neem the control of cochineal, neem oil being the most efficient. The extracts of $L$. 
ferrea and A. sisalana can be tested for cochineal control program in palm plantations in semiarid areas, alone or with other control methods, such as traditional control-based chemicals. Previous studies demonstrate the importance of using alternative products, replacing or linking to chemical insecticides, because of low toxicity to humans and the environment (Borges et al., 2013; Silva et al., 2015).

The association of L. ferrea and A. sisalana extracts with chlorpyrifos, acetamiprid, thiamethoxam and lambda-cyhalothrin insecticides was efficient in controlling $D$. opuntiae in particular the combination of extracts with chlorpyrifos insecticide, killing more than $90 \%$ of adult females and nymphs cochineal. The results show positive synergism of products in insect control, it is possible to decrease the concentrations of these, and especially pesticides, aiming thus a smaller impact on the environment when the products are tested on infested palm plantations by $D$. opuntiae. Likewise, Santos et al. (2015) verified the insecticidal action of the $R$. communis and P. pyramidalis extracts together with Fusarium incarnatum-equiseti species complex (FIESC) on $D$. opuntiae, and found more efficient fungus association with the $R$. communis aqueous extract, with mortality percentage of $100 \%$ D. opuntiae. The insecticides with the active principles pyrethroid, organophosphate and neonicotinoid were effective against nymphs and adult females of cochineal citrus, Praelongorthezia praelonga Douglas. The pesticides associations (bifenthrin chlorpyrifos + mineral oil and lambda-cyhalothrin methidathion + mineral oil) caused mortality of $91.50 \%$ and $95.60 \%$, respectively, after 14 days of treatment, which shows the synergistic effect of the tested products (Schinor, Martelli, Pacheco, \& Azevedo, 2011). Therefore, the association of $\mathrm{LC}_{50}$ extracts and $\mathrm{LC}_{50}$ pesticides, in particular with the insecticide chlorpyrifos could replace the pesticide use in the control of large infestations of $D$. opuntiae in field testing, which is a suggested option for employment in the environment. The combination of entomopathogenic agents with chemical insecticides or plant extracts can extend the action of these in pest control and reduce the damage caused to the environment (Amjad, Bashir, Afzal, Sabri, \& Javed, 2012; Silva, Alves, E. A. L. A. Lima, \& V. L. M. Lima, 2015; Santos et al., 2015).

\section{Conclusion}

The D. opuntiae has become an important pest for palm plantations in northeastern Brazil, and other countries like Mexico. Therefore, it is essential to use efficient methods to be used in the control of the cochineal, in order to minimize the damage of this pest in the plantations of $O$. ficus-indica.

The results show the efficacy of $L$. ferrea and A. sisalana extracts and the insecticides chlorpyrifos, acetamiprid, thiamethoxan and lambda-cyhalothrin in the control of D. opuntiae.

The extracts can be tested alone or in combination in the control of carmine cochineal, palm plantations.

\section{References}

Amjad, M., Bashir, M. H., Afzal, M., Sabri, M. A., \& Javed, N. (2012). Effects of commercial pesticides against cotton whitefly (Bemisia tabaci Genn.) and mites (Tetranychus urticae Koch) on growth and conidial germination of two species of entomopathogenic fungi. Pakistan Journal of Life and Social Sciences, 10(1), 22-27. Retrieved from http://www.pjlss.edu.pk/pdf_files/2012_1/22-27.pdf

Araújo, A. A., Soares, L. A. L., Assunção, M. R. F., Souza Neto, M. A., Silva, G. R., Araújo, R. F., Guerra, G. C. B., ... Melo, M. C. N. (2014). Quantification of polyphenols and evaluation of antimicrobial, analgesic and anti-inflammatory activities of aqueous and acetone-water extracts of Libidibia ferrea, Parapiptadenia rigida and Psidium guajava. Journal of Ethnopharmacology, 156, 88-96. https://doi.org/10.1016/ j.jep.2014.07.031

Barreto, A. F., Araújo, E., \& Bonifácio, B. F. (2010). Eficiência de extratos de Agave sisalana (Perrine) sobre o ácaro rajado Tetranychus urticae (Koch) e ocorrência de fitotoxidez em plantas de algodoeiro (Gossypium hirsutum L. latifolium Hutch). Revista Brasileira de Agroecologia, 5(2), 207-215. Retrieved from http://www.aba-agroecologia.org.br/revistas/index.php/rbagroecologia/article/view/9851/6727

Borges, L. R., Santos, D. C., Cavalcanti, V. A. L. B., Gomes, E. W. F., Falcão, H. M., \& Silva, D. M. P. (2013). Selection of cactus pear clones regarding resistance to carmine cochineal Dactylopius opuntiae (Dactylopiidae). Acta Horticulturae, 1(995), 359-365. https://doi.org/10.17660/ActaHortic.2013.995.47

Bouharroud, R., Amarraque, A., \& Qessaoui, R. (2016). First report of the Opuntia cochineal scale Dactylopius opuntiae (Hemiptera: Dactylopiidae) in Morocco. Bulletin OEPP/EPPO Bulletin, 4(2), 308-310. https://doi.org/10.1111/epp.12298 
Carvalho, F. G., Sampaio, J. P. S., Araújo, M. M. S., Pinto, L. S. S., \& Rocha, A. J. (2016). Assessment of the healing activity of jucá pods [Libidibia ferrea (Mart. ex Tul.) L. P. Queiroz] in cutaneous lesions of rats. Acta Scientiarum Technology, 38(2), 137-143. https://doi.org/10.4025/actascitechnol.v38i2.28570

Chand, N., Tiwary, R. K., \& Rohatgi, P. K. (1988). Bibliography resource structure properties of natural cellulosic fibres-an annotated bibliography. Journal of Materials Science, 23(2), 381-387. https://doi.org/ 10.1007/BF01174659

Chavez-Moreno, C. K. A., Tecante, A., \& Casas, E. A. (2009). The Opuntia (Cactaceae) and Dactylopius (Hemiptera: Dactylopiidae) in Mexico: A historical perspective of use, interaction and distribution. Biodiversity and Conservation, 18(13), 3337-3355. https://doi.org/10.1007/s10531-009-9647-X

Cheng, S. S., Chang, H. T., Wu, C. L., \& Chang, S. T. (2007). Anti-termitic activities of essential oils from coniferous trees against Coptotermes formosanus. Bioresource Technology, 98(2), 456-459. https://doi.org/ 10.1016/j.biortech.2006.01.006

Ennouri, M., Fetoui, H., Bourret, E., Zeghal, N., \& Attia, H. (2006). Influence of a seed oil supplemented diet on rats. Bioresource Technology, 97(12), 1382-1386. https://doi.org/10.1016/j.biortech.2005.07.010

Falcão, H. M., Oliveira, M. T., Mergulhão, A. C., Silva, M. V., \& Santos, M. G. (2013). Ecophysiological performance of three Opuntia ficus-indica cultivars exposed to carmine cochineal under field conditions. Scientia Horticulturae, 150, 419-424. https://doi.org/10.1016/j.scienta.2012.11.021

Flores-Hernández, A., Murillo-Amador, B., Rueda-Puente, E. O., Salazar-Torres, J. C., García-Hernández, J. L., \& Troyo-Diéguez, E. (2006). Reproduction of wild cochineal Dactylopius opuntiae (Homoptera: Dactylopiidae). Revista Mexicana de Biodiversidad, 77(1), 97-102.

Freitas, A. C. C, Ximenes, N. C. A., Aguiar, J. S., Nascimento, S. C., Lins, T. U. L., Magalhães, L. R., ... Correia, M. T. S. (2012). Biological activities of Libidibia (Caesalpinia) ferrea var. parvifolia (Mart. ex Tul.) L. P. Queiroz pod preparations. Evidence-Based Complementary and Alternative Medicine, 2012, 5141-5147. https://doi.org/10.1155/2012/514134

Galati, E. M., Mendello, M. R., Giuffrida, D., \& Miceli, N. (2001). Anticulcer activity of Opuntia ficus-indica (L.) Mill. (Cactaceae): Ultra structural study. Journal of Ethnopharmacology, 76(1) 1-9. https://doi.org/ 10.1016/S0378-8741(01)00196-9

Gorlach-Lira, K., \& Lira, B. B. (2011). Utilização do óleo nim para o controle da cochonilha-do-carmim Dactylopius opuntiae (Cockerell) em palma-forrageira. Pesquisa Agropecuária Pernambucana, 16, 18-22.

Hoffmann, J. H., Moran, V. C., \& Zimmermann, H. G. (1999). Integrated management of Opuntia stricta (Haworth) Haworth (Cactaceae) in South Africa: an enhanced role for two, renowned, insect agents. African Entomology Memoir, 1, 15-20.

Lee, J. C., Kim, H. R., Kim, J., \& Jam, Y. M. (2002). Antioxidant property of an ethanol extract of the stem of Opuntia ficus-indica var. saboten. Journal of Agricultural and Food Chemistry, 50(22), 6490-6496. https://doi.org/10.1021/jf020388c

Lorenzi, H. (2002). Árvores brasileiras: manual de identificação e cultivo de plantas arbóreas nativas do Brasil (4th ed.). São Paulo, SP: Nova Odessa, Instituto Plantarum de Estudos da Flora.

Luna, J. S., Santos, A. F., Lima, M. R. F., Omena, M. C., Mendonça, F. A. C., Bieber, L. W., ... Santana, A. E. G. (2005). A study of the larvicidal and molluscicidal activities of some medicinal plants from Northeast Brazil. Journal of Ethnopharmacology, 97(2), 199-206. https://doi.org/10.1016/j.jep.2004.10.004

Medina, E. M. D., Rodríguez, E. M. R., \& Romero, C. D. (2007). Chemical characterization of Opuntia dillenii and Opuntia ficus indica fruits. Food Chemistry, 103(1), 38-45. https://doi.org/10.1016/j.foodchem.2006. 06.064

Melo-Santos, M. A. V., Araújo, A. P., Rios, E. M. M., \& Regis, L. (2009). Long lasting persistence of Bacillus thuingiensis larvicidal activity in Aedes aegypti (Diptera: Culicidae) breeding places is associated to bacteria recycling. Biological Control, 49(2), 186-191. https://doi.org/10.1016/j.biocontrol.2009.01.011

Nobel, P. S. (2001). Ecophysiology of Opuntia ficus-indica, In C. Mondragón-Jacobo \& S. Pérez-González (Eds.), Cactus (Opuntia spp.) as forage (pp. 13-20). Rome: Food and Agriculture Organization of the United Nations (FAO). Retrieved from http://www.fao.org/docrep/005/Y2808E/y2808e06.htm

Nunes, F., Leite, J., Oliveira, L., Sousa, P., Menezes, M., Morais, J., Mascarenhas, S., ... Braga, V. (2015). The larvicidal activity of Agave sisalana against L4 larvae of Aedes aegypti is mediated by internal necrosis and 
inhibition of nitric oxide production. Parasitology Research, 114(2), 543-549. https://doi.org/10.1007/ s00436-014-4216-y

Oliveira, R. L. C., Lins-Neto, E. M. F., Araújo, E. L., \& Albuquerque, U. P. (2007). Conservation priorities and population struture of woody medicinal plants in an area of Caatinga vegetation (Pernambuco State, NE Brazil). Environmental Monitoring and Assessment, 132(1-3), 189-206. https://doi.org/10.1007/ s10661-006-9528-7

Omena, M. C., Navarro, D. M. A. F., Paula, J. E., Luna, J. S., Lima, M. R. F., \& Santana, A. E. G. (2007). Larvicidal activities agaisnst Aedes aegypti of some Brazilian medicinal plants. Bioresource Technology, 98(13), 2549-2556. https://doi.org/10.1016/j.biortech.2006.09.040

Palacios-Mendonza, C., Nieto-Hernández, R., LlanderaL-Cázares, C., \& Gonzáles-Hernándes, H. (2004). Efectividad biológica de productos biodegradables para el control dela cochinilla silvestre Dactylopius opuntiae (Cockerell) (Homptera: Dactylopiidae). Acta Zoológica Mexicana, 20(3), 99-106. Retrieved from http://www.scielo.org.mx/pdf/azm/v20n3/v20n3a7.pdf

Park, E., Kahng, J., Lee, S., \& Shin, K. (2001). An anti-inflamatory principle from cactus. Fitoterapia, 72(3), 288-290. https://doi.org/10.1016/S0367-326X(00)00287-2

Paterson, I. D., Hoffmann, J. H., Klein, H., Mathenge, C. W., Neser, S., \& Zimmermann, H. G. (2011). Biological control of Cactaceae in South Africa. African Entomology, 19(SP), 230-246. https://doi.org/ 10.4001/003.019.0221

Pérez-Ramirez, A., Castrejón-Ayala, F., \& Jiménez-Pérez, A. (2014). Potential of terpenoids and mealybug extract to deter the establishment of Dactylopius opuntiae (Hemiptera: Dactylopiidae) crawlers on Opuntia ficus-indica. Florida Entomologist, 97(1), 269-271. https://doi.org/10.1653/024.097.0137

Pourseyed, S. H., Tavassoli, M., Bermousi, I., \& Mardani, K. (2010). Metarhizium anisopliae (Ascomycota: Hypocreales): An effective alternative to chemical acaricides against different developmental stages of fowl tick Argas persicus (Acari: Argasidae). Veterinary Parasitology, 172(3-4), 305-310. https://doi.org/10.1016/ j.vetpar.2010.05.014

Santos, A. C. S., Oliveira, R. L. S., Costa, A. F., Tiago, P. V., \& Oliveira, N. T. (2015). Controlling Dactylopius opuntiae with Fusarium incarnatum-equiseti species complex and extracts of Ricinus communis and Poincianella pyramidalis. Journal of Pest Science, 89(2), 539-547. https://doi.org/10.1007/s10340-0150689-4

Santos, D. C., Farias, I., Lira, M.A., Santos, M. V. F., Arruda, G. P., Coelho, R. S., Dias, F. M., ... Melo, J. N. (2006). Manejo e utilização da palma forrageira (Opuntia e Nopalea) em Pernambuco. Empresa Pernambucana de Pesquisa Agropecuária-IPA, Recife. Retrieved from http://www.ipa.br/publicacoes tecnicas/Pal01.pdf

Sas Institute. (1999-2001). SAS user's guide: Statistics, version 8.2 (6th ed.). Cary, NC: SAS Institute.

Schinor, E. H., Martelli, I. B., Pacheco, C. A., \& Azevedo, F. A. (2011). Eficiência de inseticidas no controle de Praelongorthezia praelonga em laranjeira doce. Citrus Research \& Technology, 32(2), 93-102. https://doi.org/10.5935/2236-3122.20110011

Silva, A. P. A. P., Alves, R. T., Lima, E. A. L. A., \& Lima, V. L. M. (2015). Bioformulations in Pest Control - A Review. Annual Research \& Review in Biology, 5(6), 535-543. https://doi.org/10.9734/ARRB/2015/12395

Silva, D. M. P., Mergulhão, A. C. E. S., Medeiros, L. V., Figueiredo, M. V. B., \& Burity, H. A. (2013). Genetic variability of Dactylopius opuntiae (Hemiptera, Dactylopiidae) on forage cactus in northeast Brazil. Genetics and Molecular Research, 12(4), 5236-5246. https://doi.org/10.4238/2013.October.30.8

Souza, J. D., Silva, M. B. R., Argolo, A. C. C., Napoleão, T. H., Sá, R. A., Correia, M. T. S., ... Coelho, L. C. B. B. (2011). A new Bauhinia monandra galactose-specific lectin purified in milligram quantities from secondary roots with antifungal and termiticidal activities. International Biodeterioration \& Biodegradation, 65(5), 696-702. https://doi.org/10.1016/j.ibiod.2011.02.009

Stintzing, F. C., Schieber, A., \& Carle, R. (2001). Phytochemical and nutritional significance of cactus pear. European Food Research and Technology, 212(4), 396-407. https://doi.org/10.1007/s002170000219

Tiago, P. V., Medeiros, L. V., Leão, M. P. C., Santos, A. C. S., Costa, A. F., \& Oliveira, N. T. (2016). Polymorphisms in entomopathogenic Fusaria based on inter simple sequence repeats (ISSR). Biocontrol Science Technology, 26(10), 1401-1410. https://doi.org/10.1080/09583157.2016.1210084 
Trentin, D. S., Giordani, R. B., Zimmer, K. R., Silva, A. G., Silva, M. V., Correia, M. T. S., ... Macedo, A. J. (2011). Pontencial of medicinal plantd from the Brazilian semiarid region (Caatinga) against Staphylococcus epidermidis planktonic and biofilm lifestyles. Journal of Ethnopharmacology, 137(1), 327-335. https://doi.org/10.1016/j.jep.2011.05.030

Vázquez-García, M., Garabito-Espinoza, S., Tabares-Vega, J., \& Castillo-Herrera, G. (2011). Essential oils from aromatic plant species and insecticidal effects on Dactylopius opuntiae (Cockerell) (Homoptera: Dactylopiidae) in mobile juveniles. Acta Horticulturae, 894, 215-223. https://doi.org/10.17660/ActaHortic. 2011.894.24

Vigueras, A. L., Tovar, J. C., \& Pelayo-Ortiz, C. (2009). Use of botanicals extracts to control wild cochineal (Dactylopius opuntiae Cockerell) on Cactus Pear. Acta Horticulturae, 811(1), 299-234. https://doi.org/ 10.17660/ActaHortic.2009.811.28

Vilela, M. S., Ferreira, M. A., Azevedo, M., Modesto, E. C., Farias, I., Guimarães, A. V., ... Bispo, S. V. (2010). Effect of processing and feeding strategy of the spineless cactus (Opuntia ficus-indica Mill.) for lactating cows: Ingestive behavior. Applied Animal Behaviour Science, 125(1-2), 1-8. https://doi.org/10.1016/ j.applanim.2010.03.005

Volchansky, C. R., Hoffmann, J. H., \& Zimmerman, H. G. (1999). Host-plant affinities of two biotypes of Dactylopius opuntiae (Homoptera: Dactylopiidae) enhanced prospects for biological control of Opuntia stricta (Cactaceae) in South Africa. Journal of Applied Ecology, 36(1), 85-89. https://doi.org/10.1046/ j.1365-2664.1999.00381.x

Walker, R. P., Famiani, F., Baldicchi, A., Cruz-Castillo, J. G., \& Inglese, P. (2011). Changes in enzymes involved in photosynthesis and other metabolic processes in the fruit of Opuntia ficus indica during growth and ripening. Scientia Horticulturae, 128(3), 213-219. https://doi.org/10.1016/j.scienta.2011.01.017

Wyrepkowski, C. C., Costa, D. L. M. G., Sinhorin, A. P., Vilegas, W., Grandis, R. A., Resende, F. A., ... Santos, L. C. (2014). Characterization and quantification of the compounds of the ethanolic extract from Caesalpinia ferrea Stem Bark and evaluation of their mutagenic activity. Molecules, 19(10), 16039-16057. https://doi.org/10.3390/molecules191016039

\section{Copyrights}

Copyright for this article is retained by the author(s), with first publication rights granted to the journal.

This is an open-access article distributed under the terms and conditions of the Creative Commons Attribution license (http://creativecommons.org/licenses/by/4.0/). 